\title{
EFFECT OF FOOD AND SERVICE QUALITY ON CUSTOMER SATISFACTION A STUDY OF 3 STAR HOTELS IN PUNJAB REGION
}

\author{
SANJEEV KUMAR \& DEEPALI BHATNAGAR
}

Amity Business School, Amity University, Jaipur, India

\begin{abstract}
In this study the customer satisfaction means that how customers perceive the food and service quality of the hotel which customer becomes happier. For this point of view it is very important to understand the customer demand to fulfill the expectation of the customer as per their needs. The success of food and beverage outlet depends on its ability to satisfy the customer by providing dining. In hotel industry customer satisfaction is largely curved upon the quality of food and service. Customer satisfaction has a direct impact on organization profitability; in the study two factors identified for satisfaction of customer that is service quality, service features, food quality and future intention. ANOVA, T- test Correlation and Multiple regressions were applied on food and service quality to find out which has strong effect on customer satisfaction. Beside this research finding shows that both food quality play an important role for satisfaction of customer. It was concluded that food quality dimension had a strong impact on customer satisfaction then service quality. In the study, a survey question naire was used as the data collection technique which was developed to measure the food quality and service quality in three star hotels. There spondents are from the region of Punjab who stayed in three star hotels at Jalandhar, Chandigarh, Ludhiana and Amritsar. A total of 180 question naires were distributed, out of which 150 are received from the respondents. The 5 points Likert Scale was used for measuring the performance of food and service quality for customer satisfaction.

KEYWORDS: Customer Satisfaction, Customer Expectation, Customer Perception, Hotel Industry \& Food Quality and Service Quality
\end{abstract}

Received: Jul 10, 2017; Accepted: Jul 28, 2017; Published: Aug 03, 2017; Paper Id.: IJSMMRDAUG20175

\section{INTRODUCTION}

Hotel industry is the one of the largest and fastest growing industry in world-wide. In this industry, people come from different places and stay in the hotel. Under the umbrella of hospitality the need and wants of people away from home and get good experience interim of travel, lodging, recreation, restaurant and managed services (Walker, J R, 2010). Hotel industry is changing rapidly due to changing in the technology; hotel manager will need to be pro active in term of guest preference, food quality and changing habit of the customer (Liana Victorino, 2005). Food and beverage department is one of the major revenue producing departments of a hotel; it refer stony service rendered to gratify basic human need for hunger and the joy of eating and drinking for physiological and psychological satisfaction. Food and beverage service is the essential link between the customer and menu. The service department takes the responsibility for providing hygienic food to customers those who are staying in the hotel or walk-in guest in the restaurants. In three star categories of hotels have many food and beverage outlets such as specialty restaurants, coffee shop, bar, banquet operations, room service and executive lounge etc. In each outlet, serve different types of menu with different style of operations. There are Ala carte, Table dehote menu offered with waiter service (S. N Bagchi, 2006). Qualities of service and customer satisfaction 
are critical factors for success of any business. In order to achieve customer satisfaction, it is very important to recognize and to anticipate customer needs and to be able to satisfy them. Today's hotel industries facing one of the major challenge that to sustain the customer for longer time. In this context, positive relationships can create customer's higher commitment and increase their return rate.

\section{LITERATURE OVERVIEW}

Customer satisfaction: An overview Customer satisfaction is one of the important topic for researchers and organization to do more research, so that better result come forward and organization work hard for improving relationship with customer for their satisfaction level become high and increase the reputation of the organization in market. Satisfaction increase the customer retention and it is depends upon relationship. Customers play an important role in food service industry. Every business organization needs to keep customer happy. Good customer services are one of the make businesses successful and maintain relationships for longer time. It is very important for hotel industry always keep customers happy and fully satisfied. Special care of the guest is directly effect on economic growth (S. Margabandhu, 2014). In the service features reliability, regularity, suitability, location, safety and convenience these are the factors which play an important role in satisfaction of customers, for keeping of all these three factors focus on service quality, service feature will become long relationships with customers for future (AamnaShakeelAbbasi et al., 2010).In this study author has identifies the major two factors one is service quality and another is customer satisfaction. If organization improving the service quality on regular basis then it show effect on business and organization run successful and profit making. Many of the hotels took an initiative step for guest satisfaction by using the guest comment cards; where guest give their valuable feedback after using the services of the hotel (Ivanka Avelini Holjevac and Suzana Markovic). Customer satisfaction by using the method of Servqual model, mostly customers are satisfied with the services provided by the hotels but the major assessment of customers are on the basis of Tangibility, Reliability, Responsiveness, Assurance and (Empathy K. Karunaratne, 2010). Hotel customers are focus on two things generally one is food quality and another is service quality, these are two major areas which show the effect of business by using this process a hotel can maintained long and healthy relationship with guest in term of guest satisfaction (Ala`a Nimer,2012).There are other various factors also contributed for the satisfaction of customer, but author examine some of the important factors like food quality, service quality, restaurant environment and revisit intention (Chow Keng, 2013). The level of customer satisfaction like other than quality of food some time ambience of the restaurant, treating of guest, courtesy, friendly atmosphere, behavior and smile are the important factors which make customer satisfaction level high. Customer suggestions and comments are highly appreciated by the organizations, which can help for measuring the performance of the restaurant Cheng-Wen, 2009)

\section{Food Quality}

Food quality plays an important role in food service industry. The quality of food related with quality of raw materials, both are helpful to increase the effectiveness of the menu and it will become the selling tool for the restaurant. Food quality is one of the factors in customer evolution on different categories of restaurants. Many researchers had done research on various components which includes taste, texture, color, presentation, appearance, accompaniment and garnishes. It is predict that few of the customers revisit restaurant due to good quality of food, in studies both fast-food outlet and restaurant food quality always in rank one position as compare to other where guest take decision to revisit restaurant (Cairo, 1993). Customers show their willingness to come in the restaurant for taste of food and do revisit in future due to quality of food. Customers are ready to pay extra, if quality of food is good (Ryu et al., 2012). There are five 
other dimension of food quality that are food should be serve fresh, delicious food, nutritive value in the food, different types of menu and appealing of food to customers (Ahmad A. Al-Tit, 2015). Food quality has positive impact on customer satisfaction. The result shows that the relationship between service quality and food quality has great impact on customer satisfaction, which will help to retention of customer for future (Young, 2007).

\section{Service Quality}

The quality of service was ranked second important factor in hotel industry which customer take decision return to restaurant (Yen Neeng, 2001). Service quality and customer satisfaction both are the factors for success of any business. Hotels spending huge investment to improve the service quality, so that customer can become loyal toward the organization. A fully satisfied customer only promotes your products by Word to Mouth (WOM), which does not have any cost (Dominici. G, 2010). In any star hotel there are eight dimensions of service quality performance, feature, reliability, conformance, durability, serviceability, aesthetics, and perceived quality (Gravin,1987). Service quality is measure through perception of hotel customer; author identified seven different dimensions of SERVQUAL (tangibles, reliability, responsiveness, assurance, empathy, reasonable price and food quality) (Nur Asyura, 2010), but there is another model used for service quality that is SERVPERF model, it is new and more advance for quality measurement in Vietnam. The Cronin and Taylor proposed this model in 1992. It is a reliable and valid tool for measure the quality of service in hospitality industry. SERVPERF model will help to measure five different variables that are tangibles", "responsiveness", "empathy", "assurance" and "reliability". Study says that SERVPERF model cannot measure customer expectation about service quality in the studies of (Peter Hernon and Danuta, 1999). Service quality is regular exercises to do the assessments on regular basis for achieve the customer expectation (Parul Gupta and R.K. Srivastava, 2011).The cleanliness and hygienic of restaurant is one of the key factors which influence the choices of customer as make them loyal to particular food and beverage outlets (Chow Keng Yong, 2013). SERVQUAL model good scale for measuring the service quality and the same mode were tried by the other industries (retail sectors, airline industry, banking, telecommunication, education sectors, hospital and government sectors) and this model gave valuable result in customer expectation and customer's perception (Shahin, 2005)

$$
\text { SERVQUAL }=(\text { Performance }- \text { Expectations })
$$

\section{Revisit Intentions}

There are different ways to impress the customer to increase the revisit intention in the restaurant like interior and exterior of the restaurant, menu variety, professional staff, price factor and cleanness of the restaurant, external dimensions location, parking facilities, surrounding area of the restaurant and signage (Roy Lee and Liou Shyh Nan, 2013). There are number of factors contributed the revisit intention of the customer which includes décor, cleanliness, lighting, color, temperature, music, quality of food and service (Sulek \& Hensley, 2004). Ambience is one of the important elements, which eye- catching of the customer. Sometime food quality fails to bring back to customer (Muhamad Saufiyudin Omar et al., 2015). Decoration is also one the major element that influences the ambience of restaurant.

\section{RESEARCH OBJECTIVES}

- To assess the food and service quality satisfaction among consumer demographics.

- To find out the association between food and service quality and customer satisfaction. 
- To examine the influence of food quality and service quality on customer satisfaction.

\section{RESEARCH METHODOLOGY}

\section{The Purpose and Importance of the Study}

The objective of this research is to find out the relationship between food quality, service quality and revisit intention of the customer and to find out the whether these perceptions have an effect on their satisfaction from the service. Customer satisfaction helps to increase the efficiency that leads toim proved profit and positive impact on customers. With the increasing competition in hotel industry, customers are more demanding, so it is very important for hotel industry to understand the customer's perception toward the quality service. So keep the level high hotel industry need to do upgradation in the service quality, food quality, innovation method in cooking, quick response, reasonable price and offer something new to make the moral of customer high to revisit in the restaurant. In this context, it could be suggested that perception of food and service quality have a positive effect on customer satisfaction.

\section{Research Model}

A qualitative approach is used to explain present scenario and to examine the customer relationship with food and service quality which hotels offer to their customer.

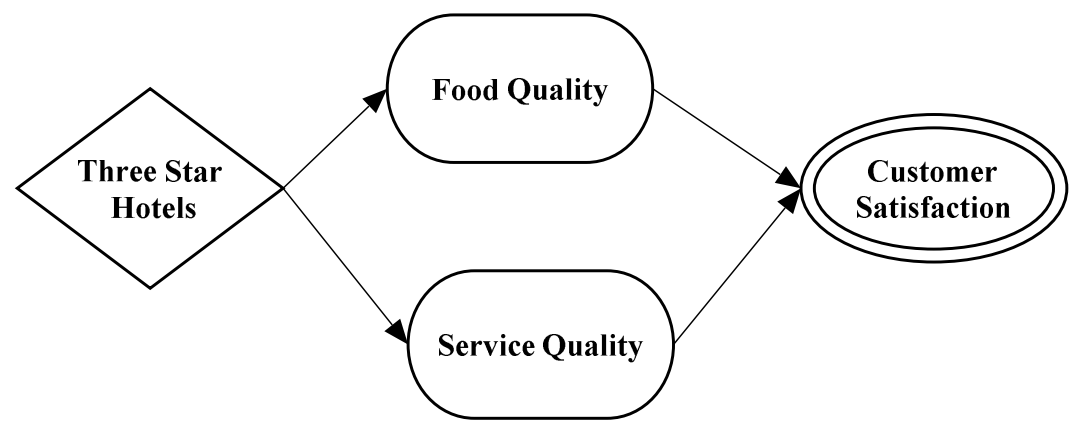

Figure 1: Theoretical Research Model of the Study

\section{The Sample of the Study and Data Collection}

This research is qualitative in nature and the design was adopted for the study. The objective of the study was to examine the relationship between food and service quality and customer satisfaction of a hotel. The study design employed two sets of variables: dependent variables are (food and service quality) and independent variable is (customer satisfaction). The questionnaire was distributed to customers who had their meal in the star hotel. There were around 05 hotels in Chandigarh and 05 hotels in the region of Punjab. There were 20 hotels were finalized for the study focus on three star categories of hotels in Punjab and Chandigarh, hotels approved by Ministry of Tourism and Government of India. In each city 5 hotels were selected to collect the data for the study, survey questionnaire was distributed to the hotel as a feedback from where customer filled after the meal. The four major cities of Punjab selected which includes Jalandhar, Amritsar, Ludhiana \& Chandigarh in this study. The research is intended for the measurement of the quality of food and service offered to customer in three star hotels in the region of Punjab. The research data were collected using the sample random sampling method, assuming 93\% confidence interval and 7\% margin of error, the sample size is calculated as $\mathrm{n}=$ 150. Taking into account the possibility of correct and incorrect or incomplete surveys, total 200 questionnaires were distributed but 150 surveys collected and included in the analysis. The questionnaire general consists of 33 questions in two different sections and used for measuring the food and service quality in three star of hotels. A 5- Points Likert scale 
was used to assess the statements in the scale where 01 represented to "Strongly disagree" and 5 represented to "Strongly agree" In addition to these questions in the scale, 06 questions on demographic like: gender, age group, marital status, education qualification, monthly income and occupation of the respondent.

\section{Formulation of Hypothesis}

For testing purpose, some of the above research objectives were converted into hypotheses. To measure the level of customers' different objectives formed the corresponding hypotheses. The same has been diagrammatically shown in bellows figure:

\section{H1: Food and Service Quality Satisfaction among Consumer Demographics}

To find out the relationship between food quality and customer satisfaction T-test and one way ANOVA applied on food and service quality for the satisfaction of consumer demographic.

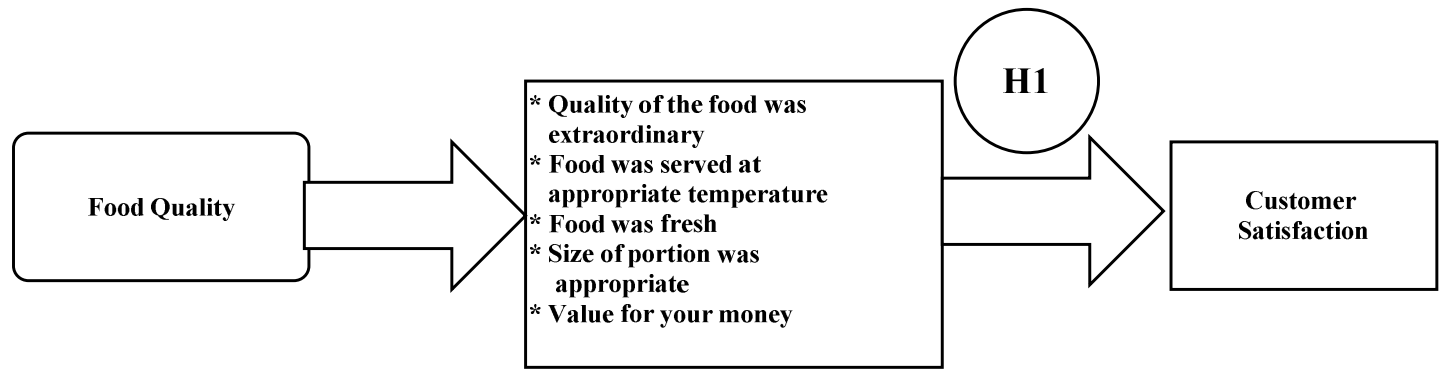

Figure 2: Conceptual Relationships between Food Quality and Customer Satisfaction

\section{H2: Association between Food and Service Quality with Customer Satisfaction}

To find out the relationship between service quality and customer satisfaction Pearson correlation method applied to find out the correlation between service quality and customer satisfaction. There were eleven variables identified to find out the relationship which have positive relation with customer satisfaction

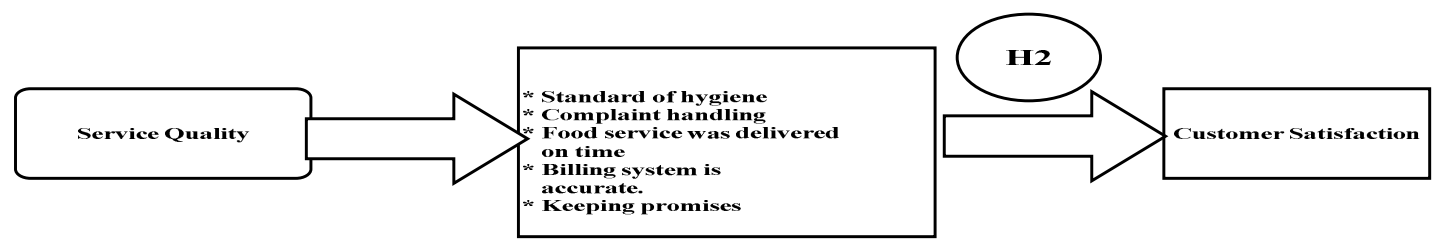

Figure 3: Conceptual Relationships between Service Quality and Customer Satisfaction

\section{H3: To Examine the Influence of Food Quality and Service Quality on Customer Satisfaction:}

To find out the association between food and service quality and customer satisfaction Linear Multiple regression method applied to find out the association

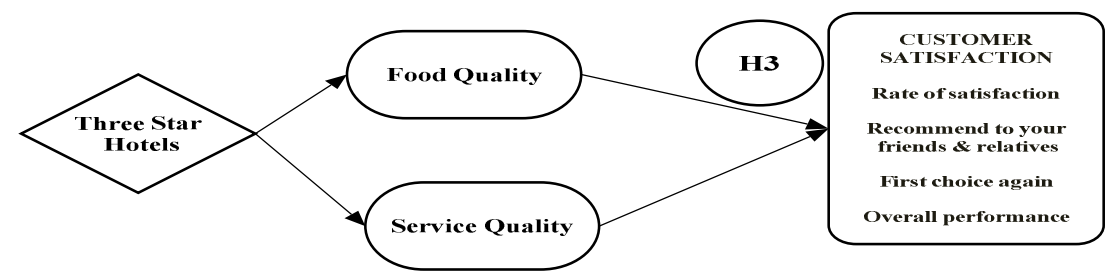

Figure 4: Influence of Food Quality and Service Quality on Customer Satisfaction 


\section{ANALYSIS OF THE RESEARCH AND INTERPRETATION OF THE FINDING}

\section{Demographic Findings}

The demographic structure of the sample was created by using the data obtained from survey. The percentage values of demographic shown as per the below table.

Table 1: Demographic Characteristics of the Sample

\begin{tabular}{|c|c|c|c|}
\hline & & Count & $\%$ Age \\
\hline \multirow{2}{*}{$\begin{array}{l}\text { Gender } \\
1 \text { (Male) } \\
2 \text { (Female) }\end{array}$} & 1 & 114 & $76.0 \%$ \\
\hline & 2 & 36 & $24.0 \%$ \\
\hline \multirow{5}{*}{$\begin{array}{l}\text { Age Group- } \\
1(18-24) \\
2(25-34) \\
3(35-44) \\
4(45-54) \\
5(55 \text { and above })\end{array}$} & 1 & 38 & $25.3 \%$ \\
\hline & 2 & 62 & $41.3 \%$ \\
\hline & 3 & 33 & $22.0 \%$ \\
\hline & 4 & 15 & $10.0 \%$ \\
\hline & 5 & 2 & $1.3 \%$ \\
\hline \multirow{5}{*}{$\begin{array}{l}\text { Martial Statues } \\
\text { 1(Single) } \\
\text { 2(Married) } \\
\text { 3(Divorced) } \\
\text { 4(Widowed) } \\
\text { 5(Would rather not say) }\end{array}$} & 1 & 78 & $52.0 \%$ \\
\hline & 2 & 67 & $44.7 \%$ \\
\hline & 3 & 1 & $0.7 \%$ \\
\hline & 4 & 2 & $1.3 \%$ \\
\hline & 5 & 2 & $1.3 \%$ \\
\hline \multirow{5}{*}{$\begin{array}{l}\text { Educational Qualifications } \\
\text { School) } \\
\text { 2(Bachelor's Degree) } \\
\text { 3(Master's } \quad \text { Degree) } \\
\text { Degree) } \\
\text { 5(Others) }\end{array}$} & 1 & 8 & $5.3 \%$ \\
\hline & 2 & 31 & $20.7 \%$ \\
\hline & 3 & 35 & $23.3 \%$ \\
\hline & 4 & 68 & $45.3 \%$ \\
\hline & 5 & 8 & $5.3 \%$ \\
\hline \multirow{5}{*}{$\begin{array}{l}\text { Monthly Income } \\
1(10000 \text { to } 20000) \\
2(20000 \text { to } 30000) \\
3(30000 \text { to } 40000) \\
4(40000 \text { to } 50000) \\
5(\text { Above } 50000) \\
\end{array}$} & 1 & 44 & $29.3 \%$ \\
\hline & 2 & 16 & $10.7 \%$ \\
\hline & 3 & 18 & $12.0 \%$ \\
\hline & 4 & 31 & $20.7 \%$ \\
\hline & 5 & 41 & $27.3 \%$ \\
\hline \multirow{5}{*}{$\begin{array}{l}\text { Occupation } \\
\text { 1(Business) } \\
\text { 2(Government Employee) } \\
\text { employed) } \\
\text { 4(Private Employee) } \\
5 \text { (Others) }\end{array}$} & 1 & 19 & $12.7 \%$ \\
\hline & 2 & 21 & $14.0 \%$ \\
\hline & 3 & 20 & $13.3 \%$ \\
\hline & 4 & 61 & $40.7 \%$ \\
\hline & 5 & 29 & $19.3 \%$ \\
\hline
\end{tabular}

As it can be seen in Table 1, the male customers are $76 \%$ and female customers $24 \%$ which $62 \%$ of customers are in the age group between 25 to 34 years and majority of customer are professional degree holder with high income and most of working in the private sector. It is observed that if the food outlet restaurant offered good quality of food and service where customers satisfied their service often increase their visit and recommend to their friend and relative by word of mouth.;

\section{DATA ANALYSIS}

\section{Objective 01: To assess the Food and Service Quality satisfaction among Consumer Demographics}

In this objective, the statistical values obtained after the T-test and one way ANOVA applied on food and service quality for the satisfaction of consumer demographic. 
$\mathbf{H}_{1 \mathbf{a}}$ : There is no difference in food and service quality between male and female customer. $\mathrm{P}<0.5$ accept the null hypothesis satisfaction with the food and service quality.

\section{T- Test by Gender}

Table 2: Customer satisfaction with Gender of Respondents

\begin{tabular}{|l|l|c|c|c|c|}
\hline \multicolumn{7}{|c|}{ Group Statistics } \\
\hline \multirow{2}{*}{ Food Quality } & Gender & $\mathbf{N}$ & Mean & $\begin{array}{c}\text { Std. } \\
\text { Deviation }\end{array}$ & $\begin{array}{c}\text { Std. Error } \\
\text { Mean }\end{array}$ \\
\cline { 2 - 6 } & Female & 114 & 4.17 & .578 & .054 \\
\hline \multirow{2}{*}{ Service Quality } & 36 & 4.07 & .661 & .110 \\
\cline { 2 - 6 } & Male & 114 & 4.16 & .641 & .060 \\
\cline { 2 - 6 } & Female & 36 & 4.12 & .711 & .119 \\
\hline
\end{tabular}

Table 3

\begin{tabular}{|c|c|c|c|c|c|c|c|c|c|c|}
\hline \multicolumn{11}{|c|}{ Independent Samples Test } \\
\hline & & \multicolumn{2}{|c|}{$\begin{array}{l}\text { Levene's Test } \\
\text { for Equality } \\
\text { of Variances } \\
\end{array}$} & \multicolumn{7}{|c|}{ T-Test for Equality of Means } \\
\hline & & \multirow[t]{2}{*}{$\mathbf{F}$} & \multirow[t]{2}{*}{ Sig. } & \multirow[t]{2}{*}{$\mathbf{T}$} & \multirow[t]{2}{*}{ Df } & \multirow[t]{2}{*}{$\begin{array}{c}\text { Sig. } \\
(2-\text { Tailed })\end{array}$} & \multirow[t]{2}{*}{$\begin{array}{c}\text { Mean } \\
\text { Difference }\end{array}$} & \multirow[t]{2}{*}{$\begin{array}{l}\text { Std. Error } \\
\text { Difference }\end{array}$} & \multicolumn{2}{|c|}{$\begin{array}{l}\text { 95\% Confidence } \\
\text { Interval of the } \\
\text { Difference }\end{array}$} \\
\hline & & & & & & & & & Lower & Upper \\
\hline \multirow{2}{*}{$\begin{array}{l}\text { Food } \\
\text { Quality }\end{array}$} & $\begin{array}{l}\text { Equal variances } \\
\text { assumed }\end{array}$ & .717 & .398 & .874 & 148 & .384 & .100 & .114 & -.126 & .326 \\
\hline & $\begin{array}{l}\text { Equal variances not } \\
\text { assumed }\end{array}$ & & & .815 & 53.002 & .419 & .100 & .123 & -.146 & .346 \\
\hline \multirow{2}{*}{$\begin{array}{l}\text { Service } \\
\text { Quality }\end{array}$} & $\begin{array}{l}\text { Equal variances } \\
\text { assumed }\end{array}$ & .579 & .448 & .314 & 148 & .754 & .039 & .126 & -.209 & .288 \\
\hline & $\begin{array}{l}\text { Equal variances not } \\
\text { assumed }\end{array}$ & & & 297 & 54.127 & .768 & .039 & . 133 & -.227 & .306 \\
\hline
\end{tabular}

Table 4

\begin{tabular}{|l|c|c|c|c|c|}
\hline \multicolumn{7}{|c|}{ Customer Satisfaction } \\
\hline & Sum of Squares & Df & Mean Square & F & Sig. \\
\hline Between Groups & 3.148 & 4 & .787 & 1.533 & .196 \\
\hline Within Groups & 74.439 & 145 & .513 & & \\
\hline Total & $\mathbf{7 7 . 5 8 8}$ & $\mathbf{1 4 9}$ & & & \\
\hline
\end{tabular}

In this part of study, sample t- test and one- way ANOVA applied to define whether there was a significance difference in food and service quality for the customer satisfaction. As a result of the analyses, the results of demographic are different from each other as shown in the above table 2. According to the results of the t- test performed in order to determine whether the participants with respect to the gender groups in term of participants' perceptions of food and service quality and customer satisfaction. When the mean value calculated, it is observed that the perceptions of male and female are assumed, there are not much difference in the satisfaction level. It found that gender perceptions towards quality of food and service not effect on customer satisfaction. 
Table 5: Customer Satisfaction with Age Group of Respondents

\begin{tabular}{|c|c|c|c|c|c|c|c|c|}
\hline \multicolumn{9}{|c|}{ Customer Satisfaction Descriptive } \\
\hline & \multirow[t]{2}{*}{$\mathbf{N}$} & \multirow[t]{2}{*}{ Mean } & \multirow{2}{*}{$\begin{array}{c}\text { Std. } \\
\text { Deviation }\end{array}$} & \multirow{2}{*}{$\begin{array}{l}\text { Std. } \\
\text { Error }\end{array}$} & \multicolumn{2}{|c|}{$\begin{array}{l}\text { 95\% Confidence Interval for } \\
\text { Mean }\end{array}$} & \multirow[t]{2}{*}{ Minimum } & \multirow[t]{2}{*}{ Maximum } \\
\hline & & & & & Lower Bound & Upper Bound & & \\
\hline $18-24$ & 62 & 4.22 & .650 & .083 & 4.06 & 4.39 & 2 & 5 \\
\hline $25-34$ & 38 & 4.21 & .770 & .125 & 3.95 & 4.46 & 2 & 5 \\
\hline $35-44$ & 33 & 4.28 & .590 & .103 & 4.08 & 4.49 & 3 & 5 \\
\hline $45-54$ & 15 & 3.76 & 1.027 & .265 & 3.19 & 4.33 & 2 & 5 \\
\hline More than 55 & 2 & 4.15 & .919 & .650 & -4.11 & 12.41 & 4 & 5 \\
\hline Total & 150 & 4.19 & .722 & .059 & 4.07 & 4.30 & 2 & 5 \\
\hline
\end{tabular}

Table 6

\begin{tabular}{|c|c|c|c|c|c|}
\hline \multicolumn{7}{|c|}{ Customer Satisfaction } \\
\hline & Sum of Squares & Df & Mean Square & F & Sig. \\
\hline Between Groups & 3.148 & 4 & .787 & 1.533 & .196 \\
\hline Within Groups & 74.439 & 145 & .513 & & \\
\hline Total & 77.588 & 149 & & & \\
\hline
\end{tabular}

In One Way ANOVA test there is no difference between in age group in the various categories of the age group.

$\mathbf{H}_{\mathbf{1 b}}$ : Hence there is $\mathrm{P}$ value is.196 which is more than $\mathrm{P}$ value and it is conclude that the null hypothesis is accepted and there is no difference in the age group for satisfaction of customer.

Table 7: Customer Satisfaction with Marital Status of Respondents

\begin{tabular}{|l|c|c|c|c|c|c|c|c|}
\hline \multicolumn{8}{|c|}{ Customer Satisfaction } \\
\hline & $\mathbf{N}$ & Mean & $\begin{array}{c}\text { Std. } \\
\text { Deviation }\end{array}$ & $\begin{array}{c}\text { Std. } \\
\text { Error }\end{array}$ & $\begin{array}{c}\text { 95\% Confidence Interval for } \\
\text { Mean }\end{array}$ & Minimum & Maximum \\
\cline { 5 - 9 } & & & & & Lower Bound & Upper Bound & & \\
\hline Single & 78 & 4.25 & .587 & .067 & 4.12 & 4.38 & 2 & 5 \\
\hline Married & 67 & 4.16 & .780 & .095 & 3.97 & 4.35 & 2 & 5 \\
\hline Divorced & 1 & 4.80 &. &. &. &. & 5 & 5 \\
\hline Windowed & 2 & 3.40 & 1.273 & .900 & -8.04 & 14.84 & 3 & 4 \\
\hline Would rather not say & 2 & 2.90 & 1.980 & 1.400 & -14.89 & 20.69 & 2 & 4 \\
\hline \multicolumn{1}{|c}{ Total } & $\mathbf{1 5 0}$ & $\mathbf{4 . 1 9}$ & $\mathbf{. 7 2 2}$ & $\mathbf{. 0 5 9}$ & $\mathbf{4 . 0 7}$ & $\mathbf{4 . 3 0}$ & $\mathbf{2}$ & $\mathbf{5}$ \\
\hline
\end{tabular}

Table 8

\begin{tabular}{|l|c|c|c|c|c|}
\hline \multicolumn{7}{|c|}{ Customer Satisfaction } \\
\hline & Sum of Squares & df & Mean Square & F & Sig. \\
\hline Between Groups & 5.276 & 4 & 1.319 & 2.645 & .036 \\
\hline Within Groups & 72.312 & 145 & .499 & & \\
\hline Total & 77.588 & 149 & & & \\
\hline
\end{tabular}

$\mathbf{H}_{1 \mathbf{c}}$ : Hence there is $\mathrm{P}$ value is.036 which is more than $\mathrm{P}$ value and it is conclude that the null hypothesis is accepted and there is no difference in the marital status for satisfaction of customer. 
Table 9: Customer Satisfaction Concerning Education Qualification of Respondents

\begin{tabular}{|c|c|c|c|c|c|c|c|c|}
\hline \multicolumn{9}{|c|}{ Descriptive } \\
\hline \multicolumn{9}{|c|}{ Customer Satisfaction } \\
\hline & \multirow[t]{2}{*}{$\mathbf{N}$} & \multirow[t]{2}{*}{ Mean } & \multirow{2}{*}{$\begin{array}{c}\text { Std. } \\
\text { Deviation }\end{array}$} & \multirow{2}{*}{$\begin{array}{l}\text { Std. } \\
\text { Error }\end{array}$} & \multicolumn{2}{|c|}{\begin{tabular}{|c|}
$95 \%$ Confidence Interval for \\
Mean
\end{tabular}} & \multirow[t]{2}{*}{ Minimum } & \multirow[t]{2}{*}{ Maximum } \\
\hline & & & & & Lower Bound & Upper Bound & & \\
\hline High school & 8 & 4.35 & .283 & .100 & 4.11 & 4.59 & 4 & 5 \\
\hline Bachelor degree & 31 & 4.13 & .712 & .128 & 3.87 & 4.39 & 2 & 5 \\
\hline Master degree & 35 & 4.24 & .763 & .129 & 3.98 & 4.50 & 2 & 5 \\
\hline Professional degree & 68 & 4.14 & .778 & .094 & 3.95 & 4.33 & 2 & 5 \\
\hline Other & 8 & 4.38 & .311 & .110 & 4.12 & 4.63 & 4 & 5 \\
\hline Total & 150 & 4.19 & .722 & .059 & 4.07 & 4.30 & 2 & 5 \\
\hline
\end{tabular}

Table 10

\begin{tabular}{|c|c|c|c|c|c|}
\hline \multicolumn{7}{|c|}{ Customer Satisfaction } \\
\hline & Sum of Squares & Df & Mean Square & F & Sig. \\
\hline Between Groups & .838 & 4 & .210 & .396 & .811 \\
\hline Within Groups & 76.750 & 145 & .529 & & \\
\hline Total & 77.588 & 149 & & & \\
\hline
\end{tabular}

$\mathbf{H}_{\mathbf{1 d}}$ : Hence there is $\mathrm{P}$ value is.811 which is more than $\mathrm{P}$ value and it is conclude that the null hypothesis is accepted and there is no difference in the education qualification for satisfaction of customer.

\section{Descriptive}

Table 11: Customer Satisfaction with Income of Respondents

\begin{tabular}{|c|c|c|c|c|c|c|c|c|}
\hline & $\mathbf{N}$ & Mean & \multirow{2}{*}{$\begin{array}{c}\text { Std. } \\
\text { Deviation }\end{array}$} & $\begin{array}{c}\text { Std. } \\
\text { Error }\end{array}$ & \multicolumn{2}{|c|}{$\begin{array}{c}\text { 95\% Confidence Interval for } \\
\text { Mean }\end{array}$} & \multirow{2}{*}{ Minimum } & Maximum \\
\cline { 5 - 8 } & & & & & Lower Bound & Upper Bound & & \\
\hline $10000-20000$ & 44 & 4.32 & .547 & .082 & 4.16 & 4.49 & 2 & 5 \\
\hline $20000-30000$ & 16 & 4.38 & .201 & .050 & 4.27 & 4.49 & 4 & 5 \\
\hline $30000-40000$ & 18 & 4.13 & .888 & .209 & 3.69 & 4.57 & 2 & 5 \\
\hline $40000-50000$ & 31 & 4.16 & .824 & .148 & 3.86 & 4.46 & 2 & 5 \\
\hline Above 50000 & 41 & 4.00 & .828 & .129 & 3.74 & 4.26 & 2 & 5 \\
\hline Total & $\mathbf{1 5 0}$ & $\mathbf{4 . 1 9}$ & $\mathbf{. 7 2 2}$ & $\mathbf{. 0 5 9}$ & $\mathbf{4 . 0 7}$ & $\mathbf{4 . 3 0}$ & $\mathbf{2}$ & $\mathbf{5}$ \\
\hline
\end{tabular}

Table 12

\begin{tabular}{|l|c|c|c|c|c|}
\hline \multicolumn{7}{|c|}{ Customer Satisfaction } \\
\hline & Sum of Squares & Df & Mean Square & F & Sig. \\
\hline Between Groups & 2.883 & 4 & .721 & 1.399 & .237 \\
\hline Within Groups & 74.705 & 145 & .515 & & \\
\hline Total & 77.588 & 149 & & & \\
\hline
\end{tabular}

$\mathbf{H}_{1 \mathrm{e}}$ : Hence there is $\mathrm{P}$ value is.237 which is more than $\mathrm{P}$ value and it is conclude that the null hypothesis is accepted and there is no difference in income for satisfaction of customer.

\section{Objective 02: Association between Food and Service Quality and Customer satisfaction}

In figure $2 \& 3$, the correlation between food and service quality indicates the customer satisfaction, Person Correlation Analysis index is used in table 7. The customer satisfactions have been calculated five different dimensions in 
each category. The average is calculated of food and service variable and the positive sign of correlation indices shows relation of variables, so that food and service quality have significant relation with customer satisfaction.

Table 13: Independent Variables: Food and Service; Dependent Variable: Customer Satisfaction

\begin{tabular}{|c|c|c|c|c|}
\hline \multicolumn{5}{|c|}{ Correlations } \\
\hline & & Food Quality & Service Quality & $\begin{array}{c}\text { Customer } \\
\text { Satisfaction }\end{array}$ \\
\hline \multirow{3}{*}{ Food Quality } & Pearson Correlation & 1 & $.800^{* *}$ & $.819^{* *}$ \\
\hline & Sig. (2-tailed) & & .000 & .000 \\
\hline & $\mathrm{N}$ & 150 & 150 & 150 \\
\hline \multirow{3}{*}{ Service Quality } & Pearson Correlation & $.800^{* *}$ & 1 & $.794^{* *}$ \\
\hline & Sig. (2-tailed) & .000 & & .000 \\
\hline & $\mathrm{N}$ & 150 & 150 & 150 \\
\hline \multirow{3}{*}{$\begin{array}{l}\text { Customer } \\
\text { Satisfaction }\end{array}$} & Pearson Correlation & $.819^{* * *}$ & $.794^{* *}$ & 1 \\
\hline & Sig. (2-tailed) & .000 & .000 & \\
\hline & $\mathrm{N}$ & 150 & 150 & 150 \\
\hline
\end{tabular}

$\mathbf{H}_{2 \mathrm{a}}$ : There is no association with food quality; hence it is concluded that $\mathrm{P}$ value is less than $0.5 \%$ and the hypothesis is rejected. The Correlation value $\mathrm{r}=.800^{* *}$ and $\mathrm{P}$ value is. 000 hence there is strong relationship with food quality and customer satisfaction.

$\mathbf{H}_{2 \mathbf{b}}$ : There is no association with service quality; hence it is concluded that $\mathrm{P}$ value is less than $0.5 \%$ and the hypothesis is rejected. The Correlation value $\mathrm{r}=.794^{* *}$ and $\mathrm{P}$ value is. 000 hence there is strong relationship with service quality and customer satisfaction.

Objective 3: The influence of food quality and service quality on customer satisfaction.

\section{RESULTS OF REGRESSION ANALYSIS}

In this part of study, regression analysis was conducted in order to expose the impact of food and service quality variables found the food quality has impact of customer satisfaction.

Table 14: Regression Analysis Results for the Impact of Food and Service Quality on Customer Satisfaction

\begin{tabular}{|c|c|c|c|c|c|c|c|c|c|}
\hline \multicolumn{10}{|c|}{ Model Summary } \\
\hline 1 & \multirow{2}{*}{ Model } & \multirow{2}{*}{ R Square } & $\begin{array}{c}\text { Adjusted } \\
\text { R Square }\end{array}$ & $\begin{array}{c}\text { Std. Error } \\
\text { of the } \\
\text { Estimate }\end{array}$ & $\begin{array}{c}\text { R Square } \\
\text { Change }\end{array}$ & F Change & df1 & df2 & Sig. F Change \\
\hline 1 & & .724 & .721 & .38137 & .724 & 193.222 & 2 & 147 & .000 \\
\hline
\end{tabular}

Table 15

\begin{tabular}{|c|c|c|c|c|c|c|}
\hline \multicolumn{7}{|c|}{ Coefficients } \\
\hline & \multirow{2}{*}{ Model } & \multicolumn{2}{|c|}{ Unstandardized Coefficients } & \multirow{2}{*}{$\frac{\text { Standardized Coefficients }}{\text { Beta }}$} & \multirow{2}{*}{$\mathbf{T}$} & \multirow{2}{*}{ Sig. } \\
\hline & & $\mathbf{B}$ & Std. Error & & & \\
\hline \multirow{3}{*}{1} & (Constant) & -.125 & .222 & & -.563 & .575 \\
\hline & Food quality & .616 & .087 & .510 & 7.070 & .000 \\
\hline & Service quality & .424 & .079 & .386 & 5.347 & .000 \\
\hline
\end{tabular}




\section{Multiple Linear Regressions:}

Customer Satisfaction $=-0.115+(0.601 *$ Food Quality $)+(0.431 *$ Service Quality $)$

$$
\mathrm{N}=150 \mathrm{R}=0.851 \quad \mathrm{Rsqr}=0.724 \quad \text { AdjRsqr }=0.721
$$

In the table 8 explained. It is observed that the effect of food quality on customer satisfaction has $61 \%$ and service quality impact on customer satisfaction has only $42 \%$. Accordingly, food and service have a significant and positive effect on customer satisfaction. Moreover, as shown in the results the value of beta effect on food quality sub- dimension on customer satisfaction are higher than service quality sub- dimension. Food quality and service quality both independent variables are significant effect on customer satisfaction due to their $\mathrm{P}$ value is less than $0.5 \%$ i.e. $\mathrm{T}$ value of food 7.07, 000 $\&$ service quality value is $5.34, .000$.

$\mathrm{H}_{3 \mathrm{a}}$ There is no association with food quality and customer satisfaction.

$\mathrm{H}_{3 \mathrm{~b}}$ There is no association with service quality and customer satisfaction

\section{CONCLUSIONS AND SUGGESTIONS}

This study investigated the customer perceptions of service quality and their effect on customer satisfaction on the basis of service offered by the three star hotels in the region of Punjab and Chandigarh. It was found that perceptions of the customer towards service were not very high; then the food quality. Therefore it is suggested to every organization to maintain the basic standard of the service in the star hotels. Every star hotel has own SOP's which need to be followed at the time of service for customer satisfaction. Hotel administrative and managers should pay special attention to improve the service standard of the hotels and provide training to their staff members and motivate them to increase the standard of the service at the time of serving customers. Finally, the result of this research show that in all fivefold dimension of service quality customer's expectations are beyond their perceptions. In fact, this research finding show that, all fivefold dimensions of service quality have less impact on customer satisfaction than on food quality. The result of service quality correlation shows that the $r=.794^{* *}$ and food quality $r=.819^{* * *}$

On the other hand food quality has strong relation with customer satisfaction. Liner Multiple Regression shows the beta value results that food quality has high effect than service quality. The effect of food quality on customer satisfaction has $61 \%$ and service quality impact on customer satisfaction has only $42 \%$. In addition, finding of this research shows that there is a positive and meaningful relation of all food and service variables for the satisfaction of customer. The result of the study clearly indicates that food and service quality is one of the key factors which influence the choice of customers as make them satisfied to particular F\&B outlet.

Implication of Study: In order to keep performance of the star hotel, the hotel should take feedback from their customer related to quality of food and service and take appropriate action to provide better service and quality of food for maintain of long relationship with customer. It can also helpful for hotel business and growth of hotel. The food service operators should continue to improving all the dimensions in order to exceed their expectation. Food service operators should carefully design their menu and set their SOP's in the operation areas to deliver a relaxed and comfortable dining. Restaurant managers may develops and measure the benchmark scores for the attributes that would boost customer loyalty and compare them with their competitors. 


\section{REFERENCES}

1. Sulek, J. M., \& Hensley, R. L. (2004). The relative importance of food, atmosphere, and fairness of wait. Cornell Hotel and Restaurant Administration Quarterly, 45(3), 235-247.

2. Ha, J., \& Jang, S. (2010). Effects of service quality and food quality: The moderating role of atmospherics in an ethnic restaurant segment. International Journal of Hospitality Management, 29(3), 520-529.

3. Cronin, J. J., \& Taylor, S. A. (1992). Measuring service quality: A reexamination and extension. Journal of Marketing, 56(3), $55-68$.

4. Walker, J. R. (2010). Hospitality Management chapter 01. Pearson.

5. Bagchi, S. (2006). Text book of food and beverage service (3rd ed.).

6. Victorina, L. (2005). Service innovation and customer choices in the hospitality industry. pp,555.

7. Ivanka Avelini Holjevac, S. M. (n.d.). Customer satisfaction measurement in hotel industry-content analysis study.

8. M.G.Saravanaraj, S. a. ( 2014). A Study on Customer Satisfaction Towards Hotel Industry in Vellore. Indian journal of applied research, 4 (2).

9. Ala'a Nimer Abu Khalifeh, A. P. (2012). Guest satisfaction and loyalty in food and beverage service department in the hotel industry. 2nd international conference on management. Retrieved from $w$ w.internationalconference.com.

10. Aamna Shakeel Abbasi, W. K. (2010). Determinants of Customer Satisfaction in Hotel Industry of Pakistan. European Journal of Scientific Research, 48 (1), pp.97-105.

11. Cheng-Wen. (2009). Excellent Food and Service towards Customer Satisfaction. Journal of Statistics and Management Systems, 12(4).

12. Asyura, N. (2010). Service quality and customer satisfaction in the hotel Industry. University of Utara Malaysia.

13. Ryu, K., Lee, H. K., \& Woo, G. (2012). The Influence of the Quality of the Physical Environment, Food, and Service on Restaurant Image, Customer Perceived Value, Customer Satisfaction, and Behavioral Intentions. International Journal of Contemporary Hospitality Management, 24(2), pp.200-223

14. Peter Hernon, D. A. (1999). Service Quality and Customer Satisfaction- An Assessment and Future Directions. The Journal of Academic Librarianship, 25 (1), pp.9-17.

15. Al-Tit, A. A. (2015). The Effect of Service and Food Quality on Customer Satisfaction and Hence Customer Retention. Asian Social Science, 11 (23).

16. Young, N., \& Soo Cheong (Shawn), J. (2007). Does Food Quality Really Matter in Restaurants? It's Impact on Customer Satisfaction and Behavioral Intentions. Journal of Hospitality \& Tourism Research, 31(3), 387-410.

17. Parul Gupta, R. S. (2011). Analysis of customer satisfaction in hotel service quality using analytic hierarchy process. International Journal of Industrial Engineering Research and Development, 2 (1), pp. 59-68.

18. Dominici, G. (2010). Customer Satisfaction in the Hotel Industry. International Journal of Marketing Studies, 2.

19. Garvin, D. A. (1987, November-December). Competing on the Eight Dimensions of Quality. Harvard Business Review, pp.101109.

20. Muhamad Saufiyudin Omar, H. F. (2015). International Journal of Administration and Governance. International Journal of Administration and Governance, 1(4), pp 1-8. 
21. Roy Lee, L. S. (2013). How the elements of arquitectural design, color, lighting and layout of a Quick-Service Restaurant Image (QSRI) influences perceived value, customer satisfaction and revisit intentions. The Asian Conference on Media and Mass Communication.

22. Sulek, J., \& Hensley, R. (2004). The relative importance of food, atmosphere, and fairness or wait: The case of a full-service restaurant. Cornell Hotel and Restaurant Administration Quarterly, 45, 235-249. 
